\title{
A ÓPERA DA FLORESTA OU A PELEJA DOS BOIS CONTRÁRIOS
}

\author{
José Guilherme dos Santos Fernandes
}

RESUMO: The different versions about the Amazonian are portrayed in several speeches about your cultural manifestations. This article intends to analyze those speeches about the bois-bumbás of the Parintins city (AM), and how those ones build the great speech about the popular culture in that area.

PALAVRAS-CHAVE: Amazônia, cultura popular, discursos.

A viagem até Parintins ${ }^{1}$ não durou mais de quatro horas e meia; ou seriam três horas e meia? A questão é que, partindo-se de Belém na direção do poente, a diferença de fuso horário entre a capital paraense e a cidade amazonense é de menos uma hora, nesta. Portanto, cronometradamente seriam 4 horas e meia de viagem, mas efetivamente durou menos uma hora, quando aterrissei, no aeroporto local, por volta das $17 \mathrm{~h} 30 \mathrm{~min}$ - coisas de uma região que dispõe de três fusos horários. De qualquer maneira, foi bem mais cômodo do que viajar por aproximadamente 60 horas de barco, desde Belém até a ilha Tupinambarana ${ }^{2}$, como carinhosamente se referem os habitantes à ínsula em que a cidade se situa, à margem direita do rio Amazonas, próxima à divisa com o Estado do Pará. Em linha reta, teria percorrido aproximadamente $1.600 \mathrm{~km}$, se houvesse um vôo sem escalas; mas antes tive que parar em Altamira, Santarém e Itaituba, cidades paraenses, o que alongou a viagem em pelo menos mais $500 \mathrm{Km}$. Tudo isso reflete números grandiosos de tempo e espaço para se ir tão-somente de um Estado a outro, e, ainda o mais surpreendente para o morador de outras regiões brasileiras, Estados que são vizinhos. Toda essa portentosidade se objetivou nas palavras de Josiane Mascarenhas Lima, 26 anos, funcionária do SENAC, minha primeira interlocutora sobre o Festival Folclórico de Parintins, além de minha cicerone nos bastidores da cidade e da festa. Ainda na garupa da motocicleta em que me conduzia do aeroporto ao centro da cidade, ao saber de minha recente viagem a São Luís do Maranhão, a fim de conhecer e registrar sobre os bumbás, disse-me: "O boi de São Luís é rico em cultura, mas o de Parintins é magia, é grandioso". Qual o sentido de grandioso, ainda mais acrescido da palavra magia? Havia chegado naquele entardecer de 26 de junho de 2002 exatamente para saber o que havia de diferente e "original" nos boisbumbás de Parintins, e que era capaz de forçar uma imigração de quase 60 mil pessoas, entre turistas nacionais e estrangeiros, àquela cidade ribeirinha, nos dias 28, 29 e 30 de junho de cada ano, para acompanharem a disputa entre o Boi Caprichoso, simbolizado pela cor azul, e o Boi Garantido,

Professor da Universidade Federal do Pará. Este artigo é parte do primeiro capítulo de minha tese de doutorado, O boi de máscaras: festa, trabalho, memória e narrativa na cultura popular do Boi Tinga de São Caetano de Odivelas, PA, defendida no Programa de Pós-Graduação em Letras, da Universidade Federal da Paraíba, em março de 2004, sob a orientação da Profa. Dra. Maria Ignez Novais Ayala. Aqui, refiro-me a minha estada na cidade de Parintins, AM, a fim de fazer um estudo comparativo entre o boi-bumbá Tinga, do Pará, e os bois Caprichoso e Garantido, afamados no folclore amazonense, o que ocorreu em junho de 2002, por ocasião de pesquisa de campo.

${ }^{1}$ Cidade e município do Estado do Amazonas, localizado no médio rio Amazonas, com uma população de 90.150 habitantes (censo 2000). Sua economia, apesar do grande potencial ecoturístico, se concentra na extração e exportação de madeira e na produção de gado de leite e de corte. É importante porto da região, recebendo, inclusive, transatlânticos que se dirigem a Manaus.

${ }_{2}^{2}$ Alguns designam Tupinambarana ao arquipélago fluvial do médio rio Amazonas em que a ilha e a cidade de Parintins estão situadas; outros consideram Tupinambarana a ilha de pouco mais de $7 \mathrm{mil} \mathrm{km}^{2}$ na qual a cidade de Parintins encontra-se engastada em uma das extremidades. Em qualquer um dos casos, o nome é uma alusão aos índios tupinambás que migraram do litoral nordestino do Brasil e ali se fixaram, antes da Colonização. 
simbolizado pela cor vermelha, pelo título de campeão do Festival. Nas palavras iniciais de Josi, pude perceber, de antemão, que a peleja desses bois-bumbás era mais uma das formas indiciais em que se concretizava a clássica narrativa hiperbólica e fáustica sobre a Amazônia, construída a partir dos colonizadores luso-hispânicos ${ }^{3}$ e perpetuada nos vários discursos sobre a região, que vão da inesgotabilidade dos recursos naturais ao preservacionismo de vitrine, quase sempre discursos de fora e de outrem, que não consideram muito as concepções culturais das populações tradicionais da região.

Fazendo uma comparação com os bumbas-meu-boi de São Luís (MA), o que a Josi procurava me apresentar era a identidade cultural de Parintins, mediante as especificidades do Festival Folclórico e seus bois-bumbás: a grandiosidade e a magia. E nisso ela tinha em uníssono outra voz, desta feita a voz oficial e institucional do Governador do Estado do Amazonas, Amazonino Mendes. Folheando a Revista Oficial do XXXVII Festival Folclórico de Parintins (ano de 2002), encontrei de imediato a mensagem do governador, intitulada Uma autêntica ópera a céu aberto, que tratava do assunto:

Uma festa encantada no meio da Floresta Amazônica. Lendas, sonhos, magia... São infinitos os adjetivos que podem traduzir toda a beleza do Festival Folclórico de Parintins. Durante três dias a emoção faz o coração bater forte e o que há de mais autêntico na cultura cabocla aflora numa explosão de ritmos e coreografias. Um povo simples e humilde, que mora na beira do rio, é quem faz o espetáculo. Artistas da terra, que impressionam pela criatividade e que não deixam nada a desejar aos maiores gênios da arte popular.

De repente, a história do povo amazônico vai sendo desenhada em uma arena chamada Bumbódromo. O folclore mistura-se à realidade e no centro do espetáculo dois personagens dividem o coração de apaixonados torcedores. Garantido e Caprichoso, sinônimos de Paixão, uma febre que contagia. Quem já conhece, jamais vai esquecer.

Os novos visitantes podem ter a certeza que vão assistir a um espetáculo inigualável. Parintins está de braços abertos e tem muito mais que a festa dos bumbás a oferecer. O carinho e a hospitalidade do povo, as belezas naturais, recantos paradisíacos, cenários de sonho. Bem-vindos à ilha encantada.

A partir das falas de Josi e do governador, podemos estabelecer dois campos semânticos em torno de expressões com significados que são recorrentes tanto em um texto quanto em outro: 1) grandiosidade = "infinitos adjetivos que podem traduzir toda a beleza do festival", "emoção que faz o coração bater forte", "a história do povo amazônico", "Parintins [...] tem muito mais que a festa dos bumbás a oferecer", "Os novos visitantes [...] vão assistir a um espetáculo inigualável”; 2) magia = "festa encantada", "lendas, sonhos, magia", "recantos paradisíacos, cenários de sonho", "ilha encantada". Além desses campos semânticos, o texto oficial do governo constrói um terceiro, a partir de expressões que remetem ao sentido de povo, popular = "o que há de mais autêntico na cultura cabocla", "um povo simples e humilde, que mora na beira do rio, é quem faz o espetáculo", "os maiores gênios da arte popular", "o folclore se mistura à realidade", "o carinho e a hospitalidade do povo". Tanto o discurso individual quanto o institucional pretendem, a meu ver, construir a identidade cultural mediante a instituição de uma comunidade imaginada, na qual os três campos semânticos acima conferem imagens e representações com as quais os narradores podem se identificar. Daí o sentido de identidade como aspecto que nos caracteriza como "pertencentes" a uma ou mais culturas, e, notadamente, a uma cultura nacional; em nosso caso, a "pertença" é a uma cultura regional, ou que pelo menos quer assim aparentar. Exemplo disso é quando, no discurso do governador, é dito que "a história do povo amazônico vai sendo desenhada [...] no Bumbódromo". Junto com o aspecto da "grandiosidade", da festa e da região, é firmada a visão mágica, com adjetivações como "festa encantada", "recantos paradisíacos", "cenários de sonho" e, principalmente, "ilha encantada": esse sentido é o mais climático quando se busca na mitologia dos índios maué o significado de Parintins, que é noçoken, "floresta encantada"; alie-se a isso o mito das amazonas, que, muito provavelmente, habitaram a região tupinambarana. São visões e versões que se superpõem na afirmação de uma identidade assentada no caráter solidário da cultura, que atribui maior ênfase aos valores compartilhados. Mas como compreender esse modelo em uma sociedade dividida em classes, em que tensões e conflitos entre elas são freqüentes, nem sempre tão visíveis, embora existentes? É mais oportuno estudar as classes e segmentos sociais como portadores de subculturas (as comunidades), em

\footnotetext{
${ }^{3}$ A transplantação de narrativas do imaginário europeu é inaugurada com o nome de batismo da região. Amazônia é referência às mulheres guerreiras encontradas no rio Amazonas, na sua confluência com o rio Nhamundá, região circunvizinha a Parintins (AM), quando da expedição realizada pelo capitão espanhol Francisco de Orellana (1541-1542). Elas o atacaram com tamanha ferocidade e destreza que se assemelharam às guerreiras homônimas da Capadócia. No entender do capitão, as amazonas seriam guardiãs daquele Paraíso tropical de terra boa e fértil, rico em ouro e prata, como atestou Frei Gaspar de Carvajal, cronista da expedição. No entanto, nunca houve prova efetiva de sua existência, pois o conhecimento acerca delas foi dado por nativos aprisionados e relatado de forma vaga, incompleta e com parco vocabulário: "as histórias permaneceram, como devem permanecer, no plano do maravilhoso, à conta de um ciclo de conquistas no qual o mito sempre desempenhou função estimulante" (TOCANTINS, 2000, p. 51).
} 
que uma ou mais delas são hegemônicas, e entre estas e as demais existem relações ou polêmicas (combativas) ou transacionais (de troca). E qual a maneira mais adequada para se observar essas relações? Através de suas práticas e discursos acerca da cultura, com suas dissensões e conversões entre uns e outros. Assim é que nosso passo inicial é observar o discurso "regionalista", e por extensão nacionalista, sobre o Festival, não sem antes termos como suporte o que pensa Chaú́ (2001, p. 21) a esse respeito:

Não é por obra do acaso, mas por necessidade, que o discurso do poder é o do Estado nacional, pois a ideologia nacionalista é o instrumento poderoso da unificação social, não só porque fornece a ilusão da comunidade indivisa (a nação), mas também porque permite colocar a divisão fora do campo nacional (isto é, na nação estrangeira).

O que se quer afirmar é que o nacionalismo sempre pretendeu e pretende se associar ao popular, mediante um discurso unificador - o nacional-popular - que omite outros discursos que são diferenciadores - a diferença cultural e a hegemonia. Isso fica evidente no terceiro campo semântico do discurso oficial: "Um povo simples e humilde, que mora na beira do rio, é quem faz o espetáculo". A "descoberta do povo" é um recurso das classes hegemônicas que falseiam uma democracia ao pregar a inclusão dos subalternos. Que o povo parintinense - e quando falo povo refiro-me à sociedade como um todo - realiza a festa é inegável; mas qual o lugar de cada segmento e classe dessa sociedade na festa? As opções para se participar da festa no Bumbódromo são basicamente duas: desembolsar, para as três noites do Festival, $\mathrm{R} \$ 1.148,00$ para um camarote de até dez pessoas, ou pagar individualmente $\mathrm{R} \$ 402$ em uma arquibancada especial, ou R\$ 345,00 em uma cadeira numerada (valores do Festival de 2003); a outra opção é esperar por quase dez horas o início do evento, primeiramente em uma fila e posteriormente em um dos trinta mil lugares das arquibancadas gratuitas do Bumbódromo. Eu tive a oportunidade de presenciar isso quando, no primeiro dia do Festival, na frente da casa em que me encontrava hospedado, na Rua Armínio Prestes, a duzentos metros da arena, já havia, às onze horas, uma enorme fila a perder de vista, tanto de um lado como de outro. E o horário da primeira apresentação era somente às vinte e uma horas: o pior é que quem entra na arena não pode mais sair, sob o risco de perder o lugar. É exatamente nessas arquibancadas gratuitas que as torcidas de cada um dos bumbás passa de duas a três horas por noite (duração média da apresentação de cada boi), vibrando e fazendo evoluções várias em sintonia com o boi-bumbá; inclusive um dos itens de avaliação dos jurados é relativo à Galera (torcida), que religiosamente se arruma ou à esquerda de quem adentra o Bumbódromo, se Garantido, ou à direita, quando Caprichoso - durante a apresentação do adversário, a torcida desafeta não pode demonstrar qualquer manifestação, em total respeito para com o outro. $\mathrm{O}$ restante dos cinco mil lugares do Bumbódromo é para quem pode pagar ou é convidado dos governos estadual ou municipal ou do patrocinador, a Coca-Cola. Proporcionalmente, quem faz a festa são aqueles que dispõem de menos recursos, as classes subalternas, e que não podem aceder aos lugares mais bem posicionados, mais próximos à quadra de apresentações; mas daí a dizer que é uma festa do ribeirinho é, no mínimo, forjar uma igualdade nada evidente. O próprio nome oficial do Bumbódromo é Centro Cultural Amazonino Mendes, sem haver nenhuma referência aos históricos fundadores dos bois Caprichoso (Seu Luis Gonzaga) ou Garantido (Seu Lindolfo Monteverde).

Conversando com o Sr. Almeida ${ }^{4}$, comecei a desconstruir esses discursos sobre os bois-bumbás, a cultura cabocla e o Festival de Parintins, num exercício próximo a uma teoria crítica da cultura ${ }^{5}$, que permitisse o desvelamento do imaginário não como algo ilustrativo e identificador de uma comunidade, mas como um conjunto de imagens e representações que dessem conta de explicar e justificar uma realidade concreta e suas versões e visões. Assim é que percebi que o uníssono das vozes anteriormente ouvidas não era tão homogêneo, como queriam que transparecesse. O Sr. Almeida, por largos anos, até 1997, havia trabalhado como secretário no escritório do Caprichoso, uma espécie de setor administrativo e financeiro do bumbá. Passou boa parte de sua infância e adolescência convivendo nos terreiros e currais em que o Caprichoso se apresentava e ensaiava, convivendo próximo a Seu Luiz Gonzaga, o fundador do boi. Perguntado por mim qual o seu envolvimento com o boi em Parintins, respondeu:

\footnotetext{
${ }^{4}$ Sr. Almeida, 60 anos. Entrevistei-o em sua residência no Conjunto Novolar, em Parintins, no dia 27/06/2002, por indicação de minha cicerone, a Josi. Sua identificação é fictícia, a seu pedido. Preservamos a autenticidade do local da gravação e da data.

${ }^{5} \mathrm{O}$ que considero uma teoria crítica da cultura é muito mais uma metodologia do que um arcabouço conceitual, sendo um procedimento de inversão (ou perversão) da lógica universalista do discurso hegemônico, que em nosso caso coincide com o discurso nacional-regional-popular. É o que Chauí (2001) intitula "contradiscurso" ou discurso crítico, ou seja, o antidiscurso da ideologia que toma e se apodera do discurso ideológico, não procurando contrapor a ele um discurso "verdadeiro", mas desdobrando as contradições internas do ideológico. Adorno já se referia a essa questão como o reconhecimento de uma não-identidade no ideal de identidade dos conceitos. De um modo geral, o sentido de uma teoria crítica é o questionamento de formas do conhecimento que se apresentam falsas ou distorcidas em razão de estarem ligadas ao poder, o que é realizado principalmente pelo estudo da construção histórica dos conceitos.
} 
O meu problema é o seguinte, o problema do boi é o seguinte: todo mundo fala, conta história de boi; o boi Garantido nasceu tal tempo, Caprichoso nasceu tal tempo, e não é NADA disso, entendesse? Esses livros que saem é tudo falsidade, que antigamente as pessoas que AGORA querem ser os TAIS do boi, eles nunca se envolveram em boi, né. O boi nasceu sozinho, sem a ajuda desse pessoal, os dois, né. Eles têm origem do Maranhão, que foi do Maranhão que o Furtado Belém trouxe esse boi pra cá. Então era uma brincadeira muito diferente do que é agora. Ele trouxe esse boi pra cá e era, foi chamado de, ele trouxe como boi Galante, era o nome do boi, né!

É notável, logo em princípio, que o Sr. Almeida faz questão de ratificar que quem quer estar à frente do boi hoje não teve nenhuma relação de proximidade com a origem humilde dos bumbás, principalmente porque boi-bumbá era considerado uma atividade marginal e de pessoas "marginais" à "alta" sociedade:

Ele, o Seu Luís, com o Seu Lindolfo, eles andavam pelas festas que tinham por aí, no baixomeretrício mesmo, que eles eram gentes assim. Naquele tempo havia divisão de classes, de sociedade, aqui em Parintins. E aí eles brigaram, a gente não sabe até hoje... nem o Seu Luís nem o Seu Lindolfo nunca contaram o motivo da briga dos dois. E eles ficaram inimigos mortais. Então foi o tempo que acabou o boi, o Galante, e o Seu Luís fundou o Caprichoso. Já, quer dizer, pegou a idéia do boi e criou outro com o nome de Caprichoso. E Seu Lindolfo foi pro Aninga, um terreno que tem pra cá, uma comunidade. E lá ele botou um boi com outro nome que não era Garantido. Aí esse, esse boi do seu Lindolfo, brincava no Aninga e o Caprichoso brincava aqui. Depois o Seu Lindolfo veio pra Baixa do São José ${ }^{6}$. Foi quando ele fundou o Garantido.

Quando se trata de saber qual foi o primeiro boi a surgir em Parintins, a confusão se arma e a dúvida se instala. Pela ausência de registro oficial ${ }^{7}$, cada um diz que seu boi preferido veio antes do "contrário". Mas essa questão nos leva à certeza de que o registro da memória coletiva e individual, transmitido pela oralidade, é marca incisiva de fatos e eventos que se forjaram à margem do poder, uma vez que é unânime se relacionar, na cidade, a origem dos bois a pessoas das classes menos favorecidas: agricultores imigrantes nordestinos, pescadores e estivadores do movimentado porto da cidade, na época. E essa questão se reflete no relato do Sr. Almeida, quando fala de seu envolvimento, desde a adolescência, com o boi, por volta do final dos anos 50:

Então meu pai também pertencia à sociedade parintinense e ele não permitia que a gente se envolvesse com o boi, né! Porque achava a sociedade - naquele tempo tinha essa história de gente baixa - que só brincava em boi e pastorinha só quem era gente baixa.

$[\ldots]$

Eu fui envolvido com o boi quando eu era menino, uma vez. Com muito custo, o meu pai deixou eu brincar no boi porque eu admirava a brincadeira e tudo. E depois eu fui, eu ainda brinquei no Garantido dois, três anos. Naquele tempo, gente que pertencia à sociedade parintinense não brincava no boi. Então, eles pagavam pra gente sair no boi e eu fui. Era pago pra sair as três últimas noites no Garantido.

(Guilherme: Eles não admitiam brincar, as pessoas da sociedade, mas patrocinavam...)

É, existia, existia o seguinte naquela época: a society, o Caprichoso é, era e ainda é o boi da society... da sociedade, e o Garantido era o boi do "povão". Então como ele é lá do bairro, o pessoal quase não se envolvia. Depois que o Festival começou a tomar essa dimensão que está agora, então as pessoas da sociedade começaram a se envolver com o Garantido também.

Mesmo havendo muita névoa sobre a origem, pareceu-me lugar comum que, por outro lado, a relação de maior proximidade com o poder acercou a fundação do Caprichoso. Tudo leva a crer que, como disse o Sr. Almeida, quem trouxe a brincadeira do boi, na primeira década do século XX, para Parintins, foi José Furtado Belém, membro da aristocracia política, fiscal de rendas e ex-interventor na cidade, quando propôs a seu eleitorado, constituído principalmente por estivadores e pescadores, criar um boi semelhante ao que ele apadrinhava na Praça 14 de Janeiro, em Manaus: estava fundado o Galante, que depois passou a se chamar Caprichoso. Quem também me confirmou essa história foi o Afrânio de Jesus Lima (28 anos), enfermeiro do hospital regional de Parintins, num agradável "papo-molhado" sobre os bois. É claro que não se inviabilizou a participação dos subalternos, como os irmãos Cid, Boboí, Emídio

\footnotetext{
${ }^{6}$ Baixa do São José ou Baixa da Xanda são as duas referências ao local em que se encontra a sede do boi Garantido, também chamada de curral. Está localizada no bairro de mesmo nome, que, como à época do surgimento dos bumbás, é periferia da cidade. Daí se dizer que o Garantido é boi do "povão" e o Caprichoso é boi da "elite", por este ter lugar no bairro da Francesa, mais próximo ao centro, em terra firme e distante das "baixadas" alagadiças, na qual, em geral, a população urbana pobre e ribeirinha da região amazônica habita.

${ }^{7}$ Encontrei dificuldades em obter estudos históricos mais científicos sobre os bois parintinenses. Na ausência, tive que me contentar com textos mais jornalísticos, a saber: VALENTIN (1998) e as revistas Parintins: toada e boi-bumbá, números 1 e 3 (respectivamente de junho/2000 e junho/2002) e a revista Parintins: cultura e folclore, $\mathrm{n}^{\circ} 3$, junho/2002.
} 
Vaz, Luis Gonzaga e Lindolfo Monteverde. Afinal, a society não participava mas patrocinava a brincadeira, vista como coisa de "gente baixa".

O que ocorre é que essas nuanças da gênese dos bois acabaram virando tábula-rasa, como se fosse coisa sem importância, em detrimento de um discurso oficial unificador, de igualdade entre todos os participantes da festa. Esquecem-se, ou querem esquecer, os arautos dessa agregação que a trajetória dos bois, desde o início até os dias de hoje, determinou sua paulatina transformação de manifestação popular de rua para a folclorização e midiatização do espetáculo, questão que não é indiferente nas pesquisas sobre as culturas populares. Por mais que o Sr. Almeida fale que naquele tempo havia divisão de classe, de sociedade, em Parintins, como se hoje tudo fosse acessível e unificado na brincadeira do bumbá, o que observei foi o contrário, ou, para ser mais autêntico com os bumbás, os contrários. No afã de criar uma história que legitime a dominação, a classe hegemônica transforma um discurso social e político em discurso impessoal sobre a sociedade e a política, fazendo com que seu ponto de vista seja o ponto de vista universalizado. Assim o foi com a história oficial dos bois de Parintins, que lançou no mesmo tacho os contrários e as contradições da festa, em nome de uma "grandiosa e mágica ópera da floresta". Mas quero crer que a festa, mesmo quebrando a continuidade do cotidiano da vida social, é um excelente momento de se tratar do que é excluído e reprimido, sendo, assim, uma continuação da "sociedade diária”:

A festa continua, a tal ponto, que a existência cotidiana reproduz no seu desenvolvimento as contradições da sociedade. Ela não pode ser o lugar da subversão e da livre expressão igualitária, ou só consegue sê-lo de maneira fragmentada, porque não é apenas um movimento de unificação coletiva: as diferenças sociais e econômicas nelas se repetem (GARCÍA-CANCLINI, 1983, p. $55)$.

É visualizando a trajetória histórica dos bumbás que se pode ter a dimensão das diferenças e desigualdades omitidas quando "acredita-se" que a festa é um mecanismo de nivelamento econômico e social. Vejamos. Os bumbás de Parintins apresentam as diferenças em suas constituições basicamente quando consideramos dois aspectos: a origem, que corresponde ao "ontem", e a participação, que corresponde ao "hoje", ambos aspectos relativos aos atores sociais que construíram e que "brincam" nos bois.

É muito corrente aceitar-se que o boi veio do Maranhão, mas levanta-se a hipótese de que os índios da região, antes da Colonização, já faziam rituais (dabakuri) em que as danças se assemelhavam ao que hoje é apresentado: herança cultural ou criação de pesquisadores empenhados em inovar para cada um dos bumbás, como Odinéia Andrade? E qual a presença do negro na festa do bumbá, uma vez que toda a festa é idealizada e realizada como marcantemente indígena? Em relação a essa questão, é notória a relação de Lindolfo Monteverde, fundador do Garantido, assim como seu filho Porrotó, o herdeiro do boi, com a etnia negra, seja nos traços ou na descendência escrava. Mas de toda maneira, a festa é marcada pela construção, por vezes forçada, de uma identidade indígena. Tanto é que a clássica narrativa de Catirina e de Pai Francisco praticamente inexiste. É certo que essas personagens tradicionais do bumbameu-boi nordestino aparecem ainda na arena, mas o delírio nas apresentações ocorre quando se dá o ritual indígena, relativo ao tema que cada boi escolheu para apresentar em dado ano, geralmente ligado a alguma lenda amazônica. Nesses momentos, a tecnologia parintintin mostra-se faraônica, com bonecos gigantes que andam, movem os braços, abrem e fecham os olhos; aves mecânicas que dão vôo rasante sobre a platéia aturdida. O efeito plástico é extasiante, sempre na iminência de alguma alegoria, de dez metros ou mais de altura, metamorfosear-se: o índio se transforma em cobra-grande, do peito da cobra sai a porta-estandarte. Uma figura a parte nessa apoteose indígena é a "cunhã-poranga", que é traduzida como a mais bela moça da tribo: seu papel é fortalecer a beleza indígena. Mas, no fundo, a cunhã-poranga verte erotização para os olhares masculinos: "na dança das toadas, as cunhãs de pele lisa cor de sapoti exalam uma sensualidade que transpira por todos os poros. São caboclinhas morenas, corpos bonitos, coxas roliças, seios fartos, rijos, plenos de vigor e alegria" (VALENTIN, 1998, p. 28); é o mito moderno das amazonas que se reedita com as pretty-woman? Outro traço de origem que é omitido são as discriminações de classe, como já foi aludido, e que faziam com que nos tempos idos o boi minguasse pela ajuda de terceiros para que pudesse sair, o que não ocorre hoje, principalmente com a ajuda milionária do principal patrocinador, a Coca-Cola, que investe em média 2,5 milhões de reais em cada boi. A respeito disso, o Sr. Almeida afirmou:

Antigamente, eu me lembro que o Seu Luís Gonzaga saía de pires na mão, pedindo na rua dos grandes que tinham dinheiro pra, pra comprar alguma coisa pro boi, pra fazer. Ninguém queria dar, porque o boi era, era coisa de gente que não tinha posição na sociedade.

(Guilherme: E por que essa mudança?)

Me poupa, não (RISOS). Eu não vou falar, eu não quero falar nada porque eu não quero me comprometer. 
Mas a sua resposta estava na ponta dos dedos, quando esfregou o polegar no médio. Nesta expressão do Sr. Almeida tive a certeza de que as relações sociais e econômicas estavam intimamente ligadas à festa dos bumbás de Parintins.

As transformações que implicaram na passagem de uma manifestação popular de rua para um espetáculo de arena iniciaram quando da criação do Festival Folclórico de Parintins, no final dos anos 60. A pretexto de arrecadar dinheiro para a festividade de Nossa Senhora do Carmo, a Juventude Alegre Católica (JAC) organizou o primeiro festival, inicialmente com a participação só de quadrilhas juninas e de danças regionais. Após o segundo ano de festival, por volta de 1970, é que os bois Caprichoso e Garantido foram convidados para se apresentarem. Até então, os bumbás saíam unicamente em homenagem aos santos da quadra: Santo Antonio, São Pedro e São João; daí serem tidos como bois de promessa, particularmente no caso do Garantido, em que é voz corrente que Lindolfo Monteverde, por ter sido acometido de uma enfermidade (malária?), prometeu pôr o boi na rua todos os anos restantes de sua vida. Os bumbás, dada a sua origem, eram manifestações culturais primordialmente de rua, o que até hoje está fixado na memória do Sr. Almeida:

Pra mim, pra mim eu vejo até hoje o boi como se fosse antigamente, e... o quintal do Seu Luis Gonzaga era grande, né? Tinha um abieiro imenso no quintal e embaixo do abieiro que ensaiava o boi...

(Guilherme: Era sempre à noite?)

Era à noite os ensaios porque o boi era, naquele tempo, quem brincava boi era pescadores, estivadores, essas pessoas, e carregadores, esse pessoal aí. Aí, eles trabalhavam durante o dia, quando era à noite eles iam pro ensaio do boi. Aí o boi, ele falhava o boi, pouca gente tava ali, só a gente mesmo. Aí tinha aquele negócio do povo andar atrás do boi. O boi ia brincar na casa de seu fulano, iam todo o pessoal dali, os vizinhos iam tudinho pra lá. Naquele tempo faziam arraial na rua pra... dentro da minha casa botavam banca pra vender guloseima. Mas lá, lá mesmo no curral do boi, aí iam todo mundo, ficavam pouca gente ali. Quando era lá pelas tantas da madrugada, o boi voltava, vinha trazendo gente. Aí que eles iam vender as guloseimas deles. (Guilherme: Aí ele circulava pela cidade?)

Eles andavam, por exemplo, tinha dez casas pra brincar hoje à noite. Ele tinha que brincar todas as dez casas, não importava que ele viesse chegar na casa de seu fulano lá pela madrugada. Mas ele tinha compromisso, ele ia lá pra brincar.

(Guilherme: Era uma coisa mais popular?)

É... e era bonita a brincadeira, bonita. Eu me lembro que eu achava tão bonita assim, original mesmo, sabe! E é isso, às vezes, eu fico olhando o boi: o boi vai sair na rua como antigamente... sai com um trio elétrico imenso: não existia isso. O Seu Lindolfo cantava lá no curral do Garantido, a gente aqui na praça da Catedral ouvia ele cantar no curral, sem microfone, sem nada. Ele tinha um vozeirão imenso. Ele cantava lá, a gente ouvia aqui na praça da Catedral. Então era isso que a gente achava bonito; às vezes, na calada da noite, a gente em casa escutava a voz dele cantando lá.

Resguardadas as mudanças históricas - a cidade cresceu em tamanho e em população - e as "imprecisões" da memória, quais os "traços de origem", presentes nas lembranças do Sr. Almeida, que parecem permanecer na festa do boi? Deve-se discriminar que existe: $1^{\circ}$ ) um bumbá na memória, no costume, nas "ruas", nos bate-papos e bate-bocas dos parintinenses; e $2^{\circ}$ ) um outro bumbá na mídia, nos números da economia, para os turistas e na arena do Festival, no Bumbódromo. Eles não se subtraem, mas se somam e até se multiplicam nas histórias, a cada dia crescentes, do último festival, das suas origens, da vida e intrigas de seus fundadores e dirigentes. Eles não são excludentes e aqui está o "x" da questão: só o segundo tem tido visibilidade para o mundo, mas o certo é que os dois se dão de forma fragmentada e complementar. O que tenho procurado mostrar, com esse rápido estudo sobre os bumbás de Parintins, é o perfil do segundo bumbá, o que está mais perto do popular, podendo ser tanto o Caprichoso quanto o Garantido. E o que pode ser visível nesse bumbá, de imediato, é a contrariedade e a religiosidade, que vêm desde a sua fundação: seja na briga, de razões misteriosas e míticas, entre Luiz Gonzaga e Lindolfo, seja na criação de um boi de promessa.

É comum um torcedor do Garantido, por exemplo, ao se referir ao Caprichoso, não invocar o nome deste e sim chamá-lo de "contrário": é o boi adversário, cujo nome, em razão da rivalidade, os brincantes recusam-se a pronunciar. Atualmente, essa rivalidade não leva a freqüentes esforços físicos, como ocorria em tempos passados ("naquele tempo", a que se refere o Sr. Almeida), mas ela sobrevive na palavra, como uma marca de origem. De qualquer maneira, a expressão contrário reflete uma sociedade em que "a linguagem é uma substância e uma força material", o que é próprio de "sistemas mágicos" (sociedades míticas, uma dicotomia às sociedades históricas), complexos em que os tabus estão ligados a certas palavras, “cuja pronunciação equivaleria a invocar o próprio perigo” (KRISTEVA, 1969, p. 69-70). 
Questiono: a magia, então, estaria na própria estrutura dos bumbás, na mediação, e não mais na ritualização indígena? Ou nos dois?

Essa contrariedade, no entanto, cada vez menos pode ser vista como uma oposição e cada vez mais como uma composição, visto que sem um boi o outro não teria sentido. É como se houvesse a superação de uma dicotomia, da mesma forma que, no tocante à religiosidade, sagrado e profano se completam nos bois. Este é um outro traço de origem nos bumbás parintinenses, já que a gênese dos bois está umbilicalmente ligada à religião. Mesmo hoje, eles se apresentam primeiro nos dias santos da quadra junina e só por último nos dias do Festival. Até recentemente, no Garantido, a matança do boi só ocorria após a festividade de Nossa Senhora do Carmo, padroeira da cidade, realizada de 6 a 16 de julho. Ainda hoje, no dia de Santo Antônio, o Garantido percorre as ruas da cidade e, no dia de São João, ocorre uma ladainha em seu curral. A respeito do sagrado e do profano, escreveu o Prof. José Ubiratan Rosário (1999):

Observa-se na Amazônia, e dentro da densa cultura brasileira, que nas alegres festividades de Santos não há oposição rígida nenhuma entre o divino e o humano, mas uma integração salutar, daí o prestígio popular dos santos em suas imagens veneradas popularmente, vendo nelas uma reminiscência daquele ser sagrado/humano (o santo) que um dia foi de carne e osso como os demais mortais [...]. [texto inédito]

A questão que evidencia a separação mais notória entre o boi de rua e o boi de espetáculo é quanto à participação. Com a gradativa transição, a contrariedade entre os bois passou a ser amainada. Tanto é que no Bumbódromo cada torcida tem seu lugar predeterminado e toda e qualquer manifestação/participação em relação ao "contrário" é punida no julgamento, segundo cláusulas do Regulamento do Festival: "fica expressamente proibida a utilização pelas torcidas dos Bumbás [...] de manifestações em forma de gestos, acenos ou faixas ofensivas à Associação oposta, sob pena de nulidade dos pontos consignados ao item Galera". E até o "poder" dos desafios é minimizado, com perda de pontuação caso haja "alusões depreciativas à crença religiosa, às autoridades civis, militares e eclesiásticas, aos Poderes constituídos ou seus representantes, sendo permitido, no entanto, as toadas de desafio sem ofensa nominal à pessoa humana". Pergunto: o que são autoridades, o que é poder constituído?

Uma das marcas do popular é a bufonaria e a comicidade, que muitas vezes estão presentes em performances de personagens de folguedos e nas letras de músicas e poemas, e que têm a função de criticar o poder: torna público e denuncia a farsa do oficioso e do interdito. Mesmo com toda essa limitação à manifestação e participação do popular, o objetivo do Festival, segundo o $1^{\circ}$ artigo do Regulamento, "é preservar o 'folclore' do Boi-Bumbá, a cultura regional e estimular o espírito criativo do povo parintinense, valorizar a diversidade etno-cultural dos povos da Amazônia". Preservar para quem? Qual diversidade que se quer valorizar? Creio que a chave para a compreensão dessa questão está no fato de que a hegemonia é, antes de mais nada, a história de desagregação e dispersão da vida comunitária.

A ressemantização de objetos e práticas pelo Poder quebra a solidariedade comunitária e a propriedade comunal: ao tirar o boi da rua, as classes hegemônicas parintinenses fragmentaram a cultura das populações tradicionais. Agora, quando a subordinação não é apenas econômica e política mas também cultural, a quebra da unidade e coesão serve para alijar em nome da autoridade, já que se isolando melhor se domina: o político e o econômico ajudam na divisão técnica da sociedade. Pois nas "sociedades não-capitalistas e em muitas integradas ao capitalismo, mas possuidoras de raízes indígenas, onde persistem formas tradicionais de vida, a estrutura e a superestrutura são menos facilmente distinguíveis do que nas nossas" (GARCÍA-CANCLINI, 1983, p. 77) ${ }^{8}$.

O estudo do boi-bumbá de Parintins não pode considerar a manifestação de forma isolada, o que implica ver o espetáculo do Festival separado da construção histórica do evento e da sua produção, circulação e consumo. Caso contrário, pode-se cair na exaltação romântica da beleza do boi-bumbá e suas cunhãs-porangas, o que remete, por seu turno, à visão de grandiosidade; ou, então, pode-se incorrer na classificação folclórica de sua forma: tais características, de certa forma, já são perceptíveis no entorno e dentro do boi-bumbá de Parintins. Contrariamente, acredito que o material e o ideal devem formar uma totalidade. Segundo GARCÍA-CANCLINI (1983, p. 81),

\footnotetext{
${ }^{8}$ A respeito das sociedades pré-capitalistas, vale lembrar o que diz Diegues (2002, p. 83): "Dentro de uma perspectiva marxista (especialmente dos antropólogos neomarxistas), as culturas tradicionais estão associadas a modos de produção pré-capitalistas, próprios de sociedades em que o trabalho ainda não se tornou mercadoria, onde há grande dependência dos recursos naturais e dos ciclos da natureza, em que a dependência do mercado já existe, mas não é total. Essas sociedades desenvolveram formas particulares de manejo dos recursos naturais que não visam diretamente ao lucro, mas à reprodução social e cultural; como também percepções e representações em relação ao mundo natural marcadas pela idéia de associação com a natureza e dependência de seus ciclos. Culturas tradicionais, nessa perspectiva, são as que se desenvolvem dentro do modo de produção da pequena produção mercantill".
} 
Esta reivindicação do estudo unificado da estrutura e da superestrutura possui, também, uma importância política. O capitalismo rompe com a vivência imediata da unidade entre o material e o ideal, principalmente porque ele torna mais complexo e diversificado o processo de produção, separando as diferentes práticas humanas - a cultural, a política, a econômica - e especializando as etapas de um mesmo trabalho.

Dividindo tecnicamente a sociedade, o capitalismo impõe o seu interesse econômico e político, o que é recorrente na $O x$ fashion dos bois, vendida em butiques do Amazonas Shopping de Manaus, ou presente na fala "simples" do Sr. Almeida: "Agora, todo mundo é, fulano de tal quer ser presidente do boi, é uma honra pra ele ser presidente do boi”. As sociedades modernas e históricas fazem da imagem a mediadora na relação social entre as pessoas, e do espetáculo mais do que um conjunto de imagens: tornase a própria sociedade, parte dela e seu instrumento de unificação. Com isso, o espetáculo torna-se "a afirmação da aparência e a afirmação de toda a vida humana - isto é, social - como simples aparência”, o que leva o homem à alienação:

A alienação do espectador em favor do objeto contemplado (o que resulta de sua própria atividade inconsciente) se expressa assim: quanto mais ele contempla, menos vive; quanto mais aceita reconhecer-se nas imagens dominantes da necessidade, menos compreende sua própria existência (DEBORD, 1997, p. 16)

Com o discurso afirmativo e inclusivo, do imaginário grandioso e mágico do "espetáculo autêntico da cultura cabocla" dos bois-bumbás de Parintins, ocultam-se a negação e a exclusão de outros discursos, objetos e práticas culturais. Esquece-se que mágica é a sociedade que, mediante seus atos e palavras, produz o extraordinário, ou seja, aquilo que não está na ordem e na "naturalidade" do discurso nacional-popular - e grandiosa deve ser a diversidade de atores sociais que fazem os bois, assim como suas histórias e concepções acerca dos bumbás. Só assim teremos um sentido mais justo para as culturas populares.

\section{BIBLIOGRAFIA}

CHAUÍ, Marilena. Cultura e democracia. 9.ed. São Paulo: Cortez, 2001.

DEBORD, Guy. A sociedade do espetáculo. Rio de Janeiro: Contraponto, 1997.

DIEGUES, Antonio Carlos Santana. O mito moderno da natureza intocada. 4.ed. São Paulo: Annablume: Hucitec: NUPAUB/USP, 2002.

GARCÍA-CANCLÍNI, Nestor. As culturas populares no capitalismo. São Paulo: Brasiliense, 1983.

KRISTEVA, Julia. História da linguagem. Lisboa: Ed. 70, 1969.

REVISTA Parintins: cultura e folclore. n.3., jun. 2002.

REVISTA Parintins: toada e boi-bumbá. n. 1, jun. 2000.

REVISTA Parintins: toada e boi-bumbá. n. 3, jun. 2002.

ROSÁRIO, José Ubiratan da Silva. Superação e dicotomia sagrado/profano no contexto cultural latinoamericano. In: VI Encontro Norte-Nordeste de Antropologia, Belém (PA), 7-16 nov. 1999. [inédito]

TOCANTINS, Leandro. O rio comanda a vida: uma interpretação da Amazônia. 9.ed. Manaus: Valer, 2000.

VALENTIN, Andreas. Vermelho: um pessoal garantido/The Art and Folklore of the People of Parintins. Manaus: A. Valentin, 1998. 